\title{
Role of periodontitis in hospital-acquired pneumonia
}

M.M. El Attar, ${ }^{1}$ M.Z. Zaghloul ${ }^{2}$ and H.S. ElMenoufy ${ }^{3}$

$$
\begin{aligned}
& \text { دور التهاب دواعم الأسنان في الالتهاب الرئوي المكتسب في المستشفيات } \\
& \text { مي محمود العطار، منى زكي زغلول، هالة المنوفي }
\end{aligned}
$$

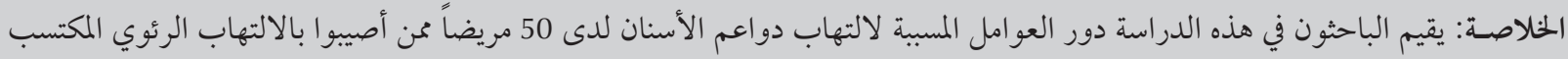

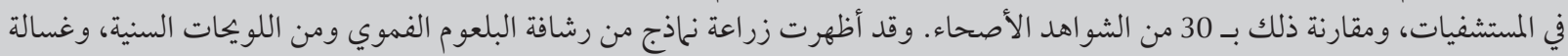

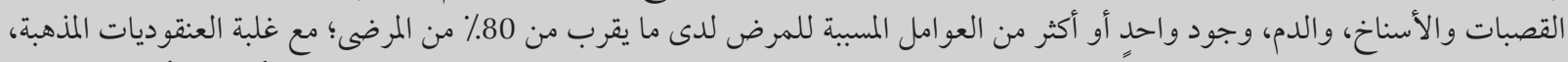

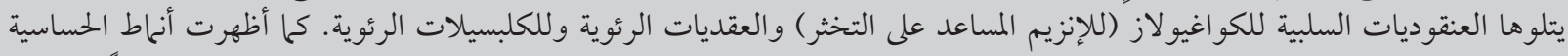

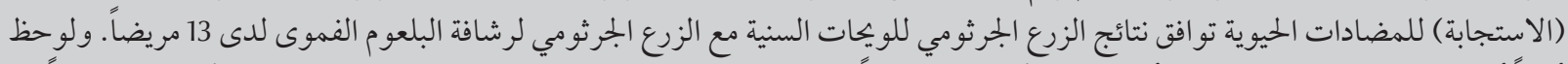

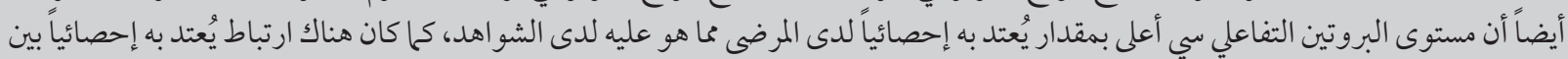

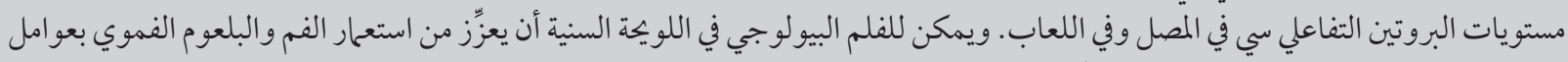

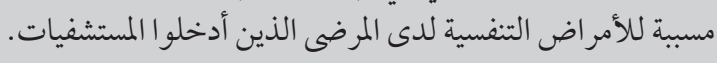

ABSTRACT This study evaluated the role of periodontal pathogens in 50 hospitalized patients with hospitalacquired pneumonia compared with 30 healthy controls. Specimens of oropharyngeal aspirate, dental plaque, bronchoalveolar lavage and blood cultured 1 or more pathogens in around $80 \%$ of patients, predominately Staphylococcus aureus, followed by coagulase-negative staphylococci, Streptococcus pneumoniae and Klebsiella pneumoniae. Antibiotic sensitivity patterns showed concordance of bacterial cultures from dental plaque and oropharyngeal cavity in 13 patients. C-reactive protein (CRP) levels were significantly higher in patients than in controls and there was a significant correlation between serum and salivary CRP levels. Dental plaque biofilm may promote oral and oropharyngeal colonization of respiratory pathogens in hospitalized subjects.

\section{Rôle de la parodontite dans la pneumonie nosocomiale}

RÉSUMÉ Cette étude évaluait le rôle des agents pathogènes périodontiques chez 50 patients hospitalisés souffrant de pneumonies nosocomiales comparés à un groupe de contrôle comprenant 30 individus sains. Des échantillons d'aspiration oropharyngée, de plaque dentaire, de lavage broncho-alvéolaire et de sang mis en culture ont fait apparaître un ou plusieurs agents pathogènes chez environ 80 \% des patients, essentiellement le Staphylococcus aureus, suivi par des staphylocoques à coagulase négative, le Streptococcus pneumoniae et la Klebsiella pneumoniae. Les schémas de sensibilité aux antibiotiques ont montré une concordance au niveau des cultures bactériennes issues de la plaque dentaire et de la cavité oropharyngée chez 13 patients. Les taux de protéine $C$ réactive étaient nettement plus élevés chez les patients que dans le groupe de contrôle et une corrélation importante a été observée entre les taux de protéine $C$ réactive sériques et salivaires. Le biofilm constitué par la plaque dentaire peut favoriser la colonisation orale et oropharyngée par des agents pathogènes respiratoires chez les sujets hospitalisés.

'Department of Chest Diseases; ${ }^{2}$ Department of Clinical Pathology, Faculty of Medicine, Ain Shams University, Cairo, Egypt (Correspondence to M.M. El Attar:may_el_attar@yahoo.com).

${ }^{3}$ Department of Oral Medicine, Peridontology and Diagnosis, Faculty of Dentistry, Future University, Cairo, Egypt.

Received: 19/05/08; accepted 16/06/08 


\section{Introduction}

There has been a recent resurgence of interest in the relationship between oral health and a number of prevalent systemic diseases [1-3]. Evidence in the last decade has suggested that infections of the oral cavity, especially periodontitis, are a risk factor for pneumonia and other respiratory diseases [4]. In the case of nosocomial or hospital-acquired pneumonia (HAP) aspiration of oral bacteria during mechanical ventilation is one possible route for contamination of the lower airways by microorganisms [4-6]. It seems logical, therefore, to evaluate the role of dental plaque as a source of these bacteria, especially in patients with periodontal disease $[7,8]$. In general, the bacterial profile of pneumonia in nonventilated hospital patients is similar to that of ventilated patients, involving multidrug-resistant pathogens such as methicillin-resistant Staphylococcus aureus, Pseudomonas aeruginosa, Enterobacter species and Klebsiella pneumoniae [9].

Periodontitis is a chronic inflammatory reaction to a specific group of bacteria that results in destruction of the supporting connective tissue and bone of the tooth structure [10]. It is a common oral infection that can affect the host's susceptibility to systemic disease in a number of ways; for example via shared risk factors such as tobacco smoking, ageing and stress; via subgingival plaque biofilms acting as a reservoir of Gram-negative anaerobic bacteria which are the main pathogens in HAP; and via gingival-crevicular fluid that contains important bioactive molecules such as enzymes and cytokines that may pass into the saliva and be aspirated $[2,11]$. C-reactive protein (CRP) levels are an indicator of host response that reflects periodontal destruction.

The aim of this study in Egypt was to evaluate the role of periodontal bacteria in the pathogenesis of HAP in highrisk patients by examining cultures and CRP levels of patients suffering from HAP and periodontitis.

\section{Methods}

\section{Sample}

The study group was 50 patients with confirmed HAP who were suffering from moderate to severe chronic periodontitis. HAP was defined as pneumonia occurring 48 hours after hospitalization and was confirmed by an increase in leukocyte counts in addition to the clinical picture. There were 39 males and 11 females, age range 45-70 years, mean age 50.5 [standard deviation (SD) 8.6] years. The study was carried out in the respiratory intensive care unit of Ain Shams University Hospitals, Cairo, over the period January to December 2007.

A group of 30 apparently healthy subjects ( 25 males and 5 females) were recruited as a control group; they were relatives of the patients. Their ages ranged from 36 to 65 years, mean 47.8 (SD 4.4) years.

The exclusion criteria for patients and controls were: known systemic disease; history and/or presence of infections other than respiratory tract infection or periodontitis; treatment with any medication that might affect serum levels of inflammatory markers; pregnant or lactating women; and current smokers.

\section{Data collection}

Medical, dental and social history was collected from both patient and control groups and their systemic condition was assessed according to the modified Cornell Medical Index [12]. Both patients and controls gave written informed consent to participate; there were no refusals. After giving consent all the patients were subjected to the following: full medical history taking and physical examination; plain chest X-ray; electrocardiogram; liver and kidney function tests; and fasting and postprandial blood glucose level.

\section{Periodontal assessment}

Periodontal assessment of patients and controls was carried out by at each standing tooth, including gingival index [13], plaque index [14], probing pocket depth and clinical attachment level. The control subjects were selected to be free from chronic periodontitis, which was confirmed by the absence of attachment loss, and the presence of probing depth $\leq 3 \mathrm{~mm}$ and gingival index $<1$ at all surfaces. Periodontal assessments were done by the same dentist/periodontologist.

Probing depth and clinical attachment levels were measured to the nearest $\mathrm{mm}$ at 6 sites on each tooth using William's graduated periodontal probe. Both probing depth and clinical attachment level scores around each tooth were totalled and divided by 6 to obtain the score for this tooth. The index score per subject was then obtained, by totalling the scores of all teeth and dividing this by the number of teeth examined.

The severity of the periodontal condition was characterized on the basis of the amount of clinical attachment loss, with moderate periodontitis defined as teeth sites exhibiting $\geq 3 \mathrm{~mm}$ and $<5$ mm clinical attachment loss and severe periodontitis as teeth sites with attachment loss $\geq 5 \mathrm{~mm}$ [15]. Each subject had at least 20 standing teeth, none of which had untreated periapical lesions $[16,17]$.

\section{Specimen collection}

Oropharyngeal aspirate (OPA) swabs were collected from patients and controls using an appropriate wash into sterile tubes for immediate culture. Bronchoalveolar lavage (BAL) specimens were obtained from patients by fiberoptic bronchoscope (Olympus, Tokyo, Japan) according to the recommended guidelines [18]. A portion of the specimens was send to the laboratory for quantitative culture within 1 hour of collection. Whole unstimulated specimens of saliva were obtained from patients and controls and stored as aliquots at $-20{ }^{\circ} \mathrm{C}$ for CRP determination. A sample of $2 \mathrm{~mL}$ blood from patients and controls was collected into 
vacutainer tubes, centrifuged and the serum was separated and stored at $-20^{\circ} \mathrm{C}$ for estimation of CRP level. Another 3 $\mathrm{mL}$ blood sample was collected from the patients and inoculated into Bactec Ped Plus blood culture vials (BectonDickinson, USA) for culture. Samples of supra- and subgingival dental plaque were collected from the patients using appropriate wash and periodontal curette. The specimens were placed in 1 $\mathrm{mL}$ broth and transferred to the laboratory within 1 hour.

\section{Tests}

Microbiological examination of OPA, $\mathrm{BAL}$ and plaque specimens were done from Gram-stained smears for detection of pus cells and microorganisms. Specimens were cultured on blood agar, MacConkey agar, chocolate agar and Sabouraud dextrose agar media. All isolates were identified by colony morphology and a set of biochemical tests [19]. Quantitative cultures of BAL were done using 104 colony-forming units $(\mathrm{CFU}) / \mathrm{mL}$ as a cut-off point for interpreting BAL cultures [20]. For blood cultures, the blood samples were inoculated into vials which were inserted into the BACTEC fluorescent series instrument for incubation. Subculture was done from positive culture vials using blood agar, MacConkey and chocolate agar media.
Antimicrobial susceptibility testing (antibiogram) was performed by the disk diffusion (Kirby-Bauer) method on similar pathogens to those isolated from patients' specimens.

CRP level was determined in serum and saliva of both patient and control groups by an enzyme-linked immunosorbent assay (ELISA) kit (CliniLab, Cairo, Egypt) according to the manufacturer's instructions.

\section{Statistical analysis}

Data were collected, tabulated and analysed using the SPSS, version 10.

\section{Results}

This study was carried on 50 patients with HAP (39 males and 11 females) and 30 controls (25 males and 5 females).

\section{Microbiological assessment}

From the control group, OPA cultures yielded only growth of normal upper respiratory tract flora, and blood cultures yielded no growths after 7 to 10 days' incubation.

Of the 50 patients with HAP, OPA specimens from 42 (84.0\%) patients yielded growth of pathogens and 8 (16.0\%) growth of normal upper respiratory tract flora. The majority of the isolates were Sta. aureus (23.8\%), followed by coagulase-negative staphylococci (19.0\%) and Str. pneumoniae (16.7\%) (Table 1).

Dental plaque specimens of 44 (88.0\%) patients yielded growth of 1 or more pathogens; Sta. aureus (31.5\%) accounted for the majority of the 54 isolates, followed by Bacteroids spp. (14.8\%), Str. pneumoniae (14.8\%) and coagulase-negative staphylococci (13.0\%) (Table 1).

All the BAL specimens of our 50 HAP patients yielded growth of pathogens. Sta. aureus (26.8\%) were cultured in the highest proportion of the 56 isolates, followed by coagulase-negative staphylococci (14.3\%), K. pneumoniae (14.2\%) and Str. pneumoniae (10.7\%) (Table 1).

The blood culture results revealed that $39(78.0 \%)$ out of the 50 HAP patients were positive for pathogens. The isolated organisms were predominately Sta. aureus (30.8\%), followed by coagulase-negative staphylococci (12.8\%), Str.pneumoniae (10.3\%) and $K$. pneumoniae (10.3\%) (Table 1).

In $10(20.0 \%)$ patients the same organism (Sta.aureus) was isolated from all 4 body sites: OPA, dental plaque, BAL and blood specimens. The isolated organisms displayed the same

\begin{tabular}{|c|c|c|c|c|c|c|c|c|}
\hline \multirow[t]{2}{*}{ Pathogen } & \multicolumn{2}{|c|}{$\begin{array}{l}\text { Oropharyngeal } \\
\text { aspirate } \\
\text { ( } n=42 \text { cultures) }\end{array}$} & \multicolumn{2}{|c|}{$\begin{array}{l}\text { Dental plaque } \\
\text { ( } n=54 \text { cultures })\end{array}$} & \multicolumn{2}{|c|}{$\begin{array}{c}\text { Broncho-alveolar } \\
\text { lavage } \\
\text { ( } n=56 \text { cultures })\end{array}$} & \multicolumn{2}{|c|}{$\begin{array}{c}\text { Blood } \\
(n=39 \text { cultures })\end{array}$} \\
\hline & No. & $\%$ & No. & $\%$ & No. & $\%$ & No. & $\%$ \\
\hline Staphylococcus aureus & 10 & 23.8 & 17 & 31.5 & 15 & 26.8 & 12 & 30.8 \\
\hline Coagulase-negative staphylococci & 8 & 19.0 & 7 & 13.0 & 8 & 14.3 & 5 & 12.8 \\
\hline Streptococcus pneumoniae & 7 & 16.7 & 8 & 14.8 & 6 & 10.7 & 4 & 10.3 \\
\hline Klebsiella pneumoniae & 5 & 11.9 & 4 & 7.4 & 8 & 14.3 & 4 & 10.3 \\
\hline Escherichia coli & 4 & 9.5 & 8 & 14.8 & 5 & 8.9 & 3 & 7.6 \\
\hline Pseudomonas aeruginosa & 2 & 4.8 & 0 & 0.0 & 3 & 5.4 & 2 & 5.1 \\
\hline Streptococcus pyogenes & 3 & 7.1 & 5 & 9.3 & 4 & 7.1 & 3 & 7.6 \\
\hline Peptostreptococcus & 3 & 7.1 & 5 & 9.3 & 0 & 0.0 & 0 & 0.0 \\
\hline Bacteroides spp. & 0 & 0.0 & 8 & 14.8 & 3 & 5.4 & 3 & 7.6 \\
\hline Haemophilus influenzae & 0 & 0.0 & 0 & 0.0 & 4 & 7.1 & 3 & 7.6 \\
\hline
\end{tabular}




\begin{tabular}{|c|c|c|c|c|c|c|c|c|}
\hline \multicolumn{9}{|c|}{$\begin{array}{l}\text { Table } 2 \text { Antimicrobial susceptibility profile of the Staphylococcus aureus isolated from oropharyngeal aspirate (OPA), dental } \\
\text { plaque, bronchoalveolar lavage (BAL) and blood specimens of } 10 \text { patients with hospital-acquired pneumonia }\end{array}$} \\
\hline \multirow{2}{*}{$\begin{array}{l}\text { Pathogen/specimen } \\
\text { type }\end{array}$} & \multicolumn{8}{|c|}{ No. of resistant isolates } \\
\hline & Oxacillin & Vancomycin & $\begin{array}{l}\text { Ampicillin/ } \\
\text { sulbactam }\end{array}$ & Erythromycin & Maxipim & Ciprofloxacin & Gentamicin & Imipinam \\
\hline \multicolumn{9}{|l|}{ Sta. aureus } \\
\hline OPA & 0 & 0 & 3 & 3 & 6 & 3 & 6 & 2 \\
\hline Plaque & 0 & 0 & 3 & 3 & 6 & 3 & 6 & 2 \\
\hline BAL & 0 & 0 & 3 & 3 & 6 & 3 & 6 & 2 \\
\hline Blood & 0 & 0 & 3 & 3 & 6 & 3 & 6 & 2 \\
\hline
\end{tabular}

antimicrobial susceptibility profile from all sites (Table 2). In 3 (6.0\%) patients the same organisms were found in 3 body sites: OPA, dental plaque and BAL specimens. These were: coagulasenegative staphylococci (1 patient), Str. pneumoniae (1 patient) and K. pneumoniae (1 patient). The isolated organisms displayed the same antimicrobial susceptibility profile (Table 3).

\section{Serological assessment}

The age, serum CRP and salivary CRP levels of HAP patients and controls are shown in Table 4. Mean CRP levels in serum and saliva of 50 HAP patients [28.9 (SD 12.0) $\mu \mathrm{g} / \mathrm{mL}$ and 11.7 (SD 6.6) $\mu \mathrm{g} / \mathrm{mL}$ respectively] were significantly higher than those in the controls [2.8 (SD 1.1) $\mu \mathrm{g} / \mathrm{mL}$ and 1.6 (SD 0.8) $\mu \mathrm{g} / \mathrm{mL}$ respectively]. The difference between HAP patients and controls with regard to serum $C R P$ and saliva $C R P$ was highly significant $\left(\chi^{2}=0.33, P<0.001\right)$.

There was significant correlation between serum CRP and saliva CRP in the HAP patients $(r=0.78)$ and controls $(r$ $=0.60)$ using Pearson correlation coefficient and by linear regression curve (Figure 1).

\section{Discussion}

Respiratoryinfection is thoughtto rely in part on the aspiration of oropharyngeal flora into the lower respiratory tract and failure of the host defence mechanisms to eliminate the contaminating bacteria, which then multiply to cause infection.
It has been suggested that dental plaque may act as a reservoir of respiratory pathogens, especially in patients with periodontal disease [21].

One or more pathogens were cultured from $88.0 \%$ of the dental plaque specimens of HAP patients. Sta. aureus accounted for the majority of the isolates, followed by Bacteroides spp., Str. pneumoniae and coagulase-negative staphylococci. Russell et al. reported that Sta. aureus and Gram-negative bacilli (E. coli and E. cloacae) and P. aeruginosa were the predominant respiratory pathogens

(a)

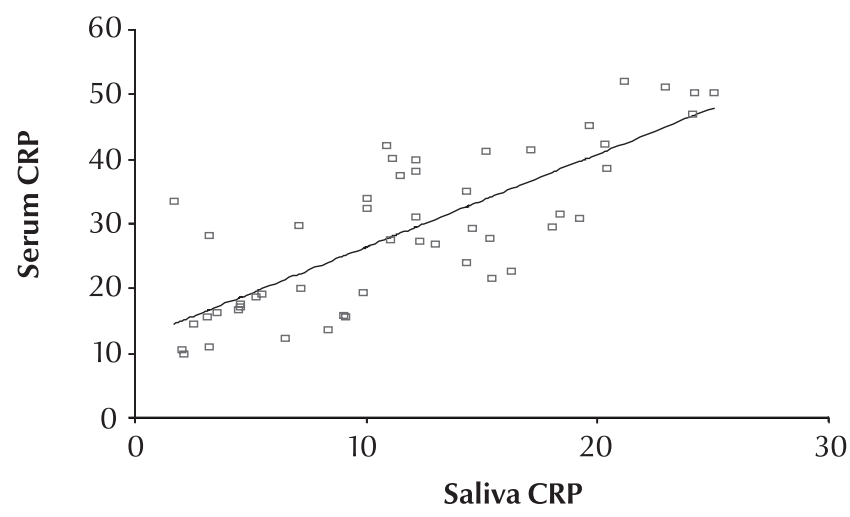

(b)

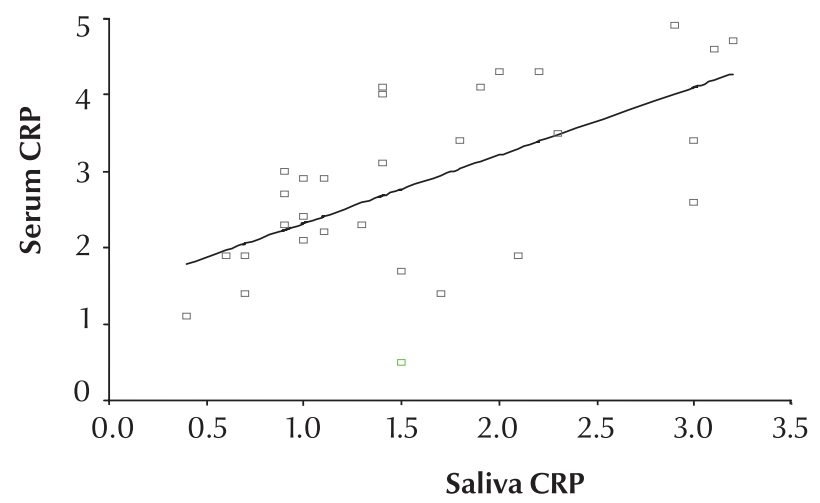

Figure 1 Linear regression curve of serum and saliva C-reactive protein (CRP) levels in (a) patients with hospital-acquired pneumonia $(n=50)$ and $(b)$ controls $(n=30)$ 


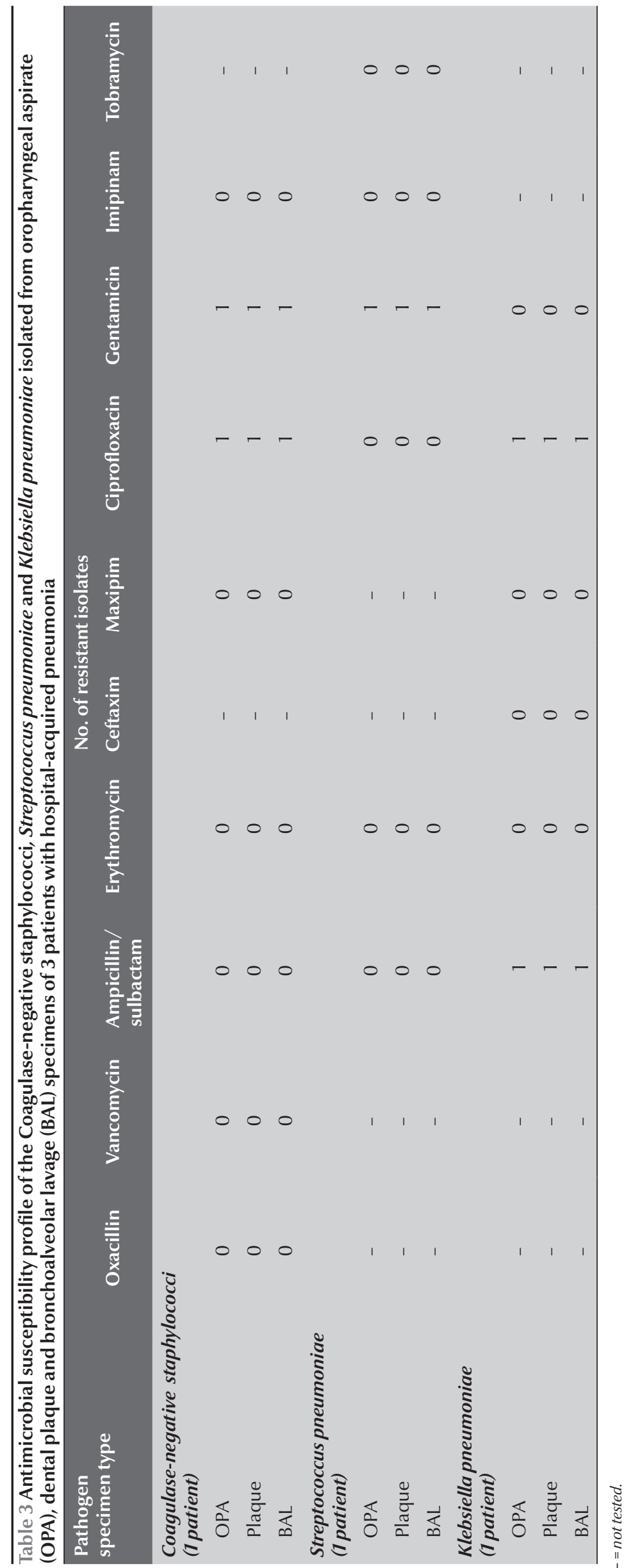

isolated from the dental plaque of institutionalized elderly people [22]. All of the BAL specimens from our $50 \mathrm{HAP}$ patients yielded growth of 1 or 2 pathogens, predominantly Sta. aureus, coagulase-negative staphylococci, $K$ pneumoniae and Str. pneumoniae. The great majority of OPA specimens from HAP patients (84.0\%) also yielded growths of pathogens: mainly Sta. aureus, coagulasenegative staphylococci and Str. pneumoniae. Scannapieco et al. reported that poor oral hygiene and periodontal disease may promote oropharyngeal colonization by potential respiratory pathogens including Enterobacteriaceae (K. pneumoniae, E. coli, Enterobacter spp.), P. aeruginosa and Sta. aureus especially in institutionalized subjects [23].

Among 54 pathogensisolated from dental plaque and 42 pathogens isolated from OPA specimens, antibiotic sensitivity patterns showed concordance of bacterial cultures between dental plaque and oropharyngeal cavity isolates in $13 \mathrm{HAP}$ patients. El-Solh et al. reported that among 33 dental plaque isolates and $36 \mathrm{OPA}$ isolates, concordance of bacterial cultures between dental plaque and the oropharyngeal cavity was observed in 20 patients, 4 of whom had developed HAP [24].

There were 3 patients who had the same organism in dental plaque, OPA and BAL specimens. The 3 isolated organisms (coagulase-negative staphylococci, Str. pneumoniae and K. pneumoniae) displayed a similar antimicrobial susceptibility profile, suggesting that the etiology of HAP in such patients could be due to aspiration of the organisms from dental plaque or OPA. We also found 10 patients with the same organism (Sta. aureus) in dental plaque, OPA, BAL and blood specimens. The isolates also had the same antimicrobial susceptibility profile, suggesting again that HAP in such patients could be due to aspiration of the organism from OPA or dental plaque or due to bacteraemia. El-Solh et al. reported in their study of 49 critically-ill patients that 14 patients developed HAP and of the 13 isolates recovered from BAL specimens of such patients, 9 showed respiratory pathogens matching those recovered from the corresponding dental plaque by antibiotic susceptibility testing: Sta. aureus 


$\begin{aligned} & \text { Table } 4 \text { Age and C-reactive protein (CRP) levels in serum and saliva of patients with hospital-acquired pneumonia (HAP) and } \\
& \text { controls }\end{aligned}$
\begin{tabular}{lcccc} 
Parameter & HAP patients $(\boldsymbol{n}=5 \mathbf{0})$ & Controls $(\boldsymbol{n}=30)$ & $\boldsymbol{t}$-value & $\boldsymbol{P}$-value \\
& Mean $(\mathrm{SD})$ & Mean $(\mathrm{SD})$ & 1.6 & 0.1 \\
Age (years) & $50.5(8.6)$ & $47.8(4.4)$ & 11.7 & $<0.001$ \\
Serum CRP $(\mu \mathrm{g} / \mathrm{mL})$ & $28.9(12.0)$ & $2.8(1.1)$ & 8.3 & $<0.001$ \\
Saliva CRP $(\mu \mathrm{g} / \mathrm{mL})$ & $11.7(6.6)$ & $1.6(0.8)$ & & \\
\hline
\end{tabular}

$S D=$ standard deviation .

(5 patients), E. coli (1 patient), E. cloacae (1 patient) and $P$. aurginosa (1 patient) [24].

Quantitative changes of specific salivary biomarkers could have significance in the diagnosis and management of both oral and systemic diseases [25]. In our study CRP levels in serum and saliva were significantly higher than those in the controls. Also there was a significant correlation between serum and salivary CRP in patients and in controls and by linear regression curve. Christodoulides et al. found significant differences in CRP levels between periodontitis patients with different grades of oral health and normal subjects [26]. Salzberoet al. in his study of 93 patients with generalized aggressive periodontitis and 91 healthy controls showed that sera from patients with periodontal infections contain elevated levels of CRP compared with individuals with good periodontal health [27].

\section{Conclusions}

Inadequate oral hygiene resulting in formation of dental plaque biofilms may promote oral and oropharyngeal colonization of respiratory pathogens which increase the risk for serious lower respiratory tract infection including pneumonia in hospitalized subjects. There is a need for frequent professional oral health care, education and provision among high-risk people in the community and those in intensive care units.

\section{Acknowledgements}

The authors thank Mr Waheed Ishac Shenouda, microbiology laboratory technician, for his generous help in preparing the microbiological media.

\section{References}

1. Stamm JW. Periodontal diseases and human health: new directions in periodontal medicine. Annals of periodontology, 1998, 3:1-2.

2. Li X et al. Systemic diseases caused by oral infection. Clinical microbiology reviews, 2000, 13(4):547-58.

3. Cabala A, Chomyszyn-Gajewska M, Drozdz W. [Periodontitis and systemic disease relationships]. Przeglad lekarski, 2006, 63(9):773-7 [in Polish].

4. Azarpazhooh A, Leake JL. Systematic review of the association between respiratory diseases and oral health. Journal of periodontology, 2006, 77(9):1465-82.

5. Loesche WJ, Lopatin DE. Interaction between periodontal disease, medical diseases and immunity in the older individual Periodontology, 2000, 1998, 16:80-105.

6. Scannapieco FA et al. Oral bacteria and respiratory infection: effects on respiratory pathogen adhesion and epithelial cell proinflammatory cytokine production. Annals of periodontology, 2001, 6:78-86.

7. Sumi $Y$ et al. High correlation between the bacterial species in denture plaque and pharyngeal microflora. Gerodontology, 2003, 20:84-7.

8. Okuda $\mathrm{K}$ et al. Involvement of periodontopathic anaerobes in aspiration pneumonia. Journal of periodontology, 2005, 76:2154-60.

9. American Thoracic Society. Guidelines for the management of adults with hospital-acquired, ventilator-associated, and healthcare-associated pneumonia. American journal of respiratory and critical care medicine, 2005, 171:388-416.

10. Katancik JA et al. Periodontitis and airway obstruction. Journal of periodontology, 2005, 76(11):2161-7.

11. Mojon P. Oral health and respiratory infection. Journal of the Canadian Dental Association, 2002, 68:340-5.

12. Kerr OA, Millard HD. Oral diagnosis, 2nd ed. St. Louis, Missouri, Mosby, 1965:17.

13. Loe $\mathrm{H}$, Silness J. Periodontal diseases in pregnancy. 1. Prevalence and severity. Acta odontologica scandinavica, 1963, 21:533-51.

14. Silness J, Loe H. Periodontal diseases in pregnancy. II. Correlation between oral hygiene and periodontal condition. Acta odontologica scandinavica, 1963, 21:533-51.

15. Armitage GC. Development of a classification system for periodontal diseases and conditions. Annals of periodontology, 1999, 4:1-6.

16. Ide $\mathrm{M}$ et al. The short-term effects of treatment of chronic periodontitis on circulating levels of endotoxins, C-reactive protein, tumor necrosis factor alpha and interleukin-6. Journal of periodontology, 2004, 75:420-8.

17. Ioannidou $\mathrm{E}$ et al. Effect of periodontal treatment on serum Creactive protein levels: a systematic review and meta-analysis. Journal of periodontology, 2006, 77:1635-42.

18. Fletcher EC et al. Bronchoscopic diagnosis of pulmonary infections. Western journal of medicine, 1983, 138:364-70. 
19. Cheesbrough M. District laboratory practice in tropical countries, part 2. Cambridge, Cambridge University Press, 2000:75.

20. Winn WC et al. Koneman's color atlas and textbook of diagnostic microbiology, 6th ed. Philadelphia, Lippincott, Williams and Wilkins, 2006:77.

21. Scannapieco FA et al. Association between oral conditions and respiratory disease in a national sample survey population. Annals of periodontology, 1998, 3(1):251-6.

22. Russell $S$ et al. Respiratory pathogen colonization of the dental plaque of institutionalized elder. Special care in dentistry, 1999, 19:128-34.

23. Scannapieco FA et al. Association between periodontal disease and risk for nosocomial bacterial pneumonia and chronic obstructive pulmonary disease: a systemic review. Annals of periodontology, 2003, 8(1):54-69.
24. El-Solh AA et al. Colonization of dental plaques: A reservoir of respiratory pathogens for hospital acquired pneumonia in institutionalized elders. Chest, 2004, 126:1575-82.

25. Pederson ED et al. Salivary levels of alpha 2-macroglobulin, alpha 1- antitrypsin, C-reactive protein, cathepsin G and elastase in humans with or without destructive periodontal disease. Archives of oral biology, 1995, 40(12):1151-5.

26. Christodoulides $\mathrm{N}$ et al. Lab-on-a-chip methods for point-ofcare measurements of salivary biomarkers of periodontitis. Annals of the New York Academy of Sciences, 2007, 1098:411-28.

27. Salzbero TN et al. C-reactive protein levels in patients with aggressive periodontitis. Journal of periodontology, 2006, 77(6):933-9.

\section{Objectives of the WHO Global Oral Health Programme}

Oral health is part of total health and essential to quality of life and WHO projects intend to translate the evidence into action programmes. The Oral Health Programme therefore gives priority to integration of oral health with general health programmes at community or national levels. The WHO Oral Health Programme works from the life-course perspective, currently community programmes for improved oral health of the elderly and of children is given high priority.

Further information about the WHO Global Oral Health Programme can be found at: http:/ / www.who.int/oral health/en/ 